\title{
Prevalence of the pathogenic crustacean virus Callinectes sapidus reovirus 1 near flow-through blue crab aquaculture in Chesapeake Bay, USA
}

\author{
Emily M. Flowers ${ }^{1}$, Andrew F. Johnson ${ }^{2}$, Robert Aguilar ${ }^{3}$, Eric J. Schott ${ }^{4, *}$ \\ ${ }^{1}$ University of Maryland School of Medicine, Baltimore, MD 21201, USA \\ ${ }^{2}$ Marine Biology Research Division, The Scripps Institution of Oceanography University of California, San Diego, \\ CA 92093, USA \\ ${ }^{3}$ Smithsonian Environmental Research Center, Edgewater, MD 21037, USA \\ ${ }^{4}$ Institute of Marine and Environmental Technology, University of Maryland Center for Environmental Science, Baltimore, \\ MD 21202, USA
}

\begin{abstract}
Understanding the ecology of diseases is important to understanding variability in abundance, and therefore management, of marine animals exploited commercially. The blue crab Callinectes sapidus fills a crucial benthic-pelagic niche in Atlantic estuarine ecosystems and supports large commercial fisheries in both North and South America. In the USA, pre-molt blue crabs are typically held in short-term shedding (ecdysis) facilities to produce soft-shell crabs of increased value. However, mortality rates in these facilities are high and commonly associated with the pathogenic C. sapidus reovirus 1 (CsRV1). To assess whether crab mortalities in these facilities might increase CsRV1 prevalence in wild crab populations, tissue sampled from crabs collected over 2 summers either near to or far from shedding facilities using flow-through water systems were tested by reverse transcription quantitative PCR (RT-qPCR) for the presence of CsRV1 RNA. In support of our hypothesis, PCR data identified the probability of detecting CsRV1 in wild crabs sampled close to shedding facilities to be $78 \%$ higher than in crabs sampled from far sites. PCR detections were also $61-72 \%$ more probable in male crabs and $21 \%$ more likely in male and female crabs over the minimum landing size. As the prevalence at which CsRV1 was detected varied within seasons, among locations and between years, blue crab migration and/or population fluctuations appear to also be involved.
\end{abstract}

KEY WORDS: Disease ecology $\cdot$ Callinectes sapidus $\cdot$ CsRV1 $\cdot$ Natural mortality

\section{INTRODUCTION}

Understanding the ecology of diseases is important to understanding variability in abundance, and therefore the management, of marine species exploited commercially (Stentiford et al. 2012). Such diseases typically receive attention only when mass mortalities or fishery impacts occur or when a pathogen is associated with aquaculture (Meyers et al. 1987, Field et al. 1992, Sánchez-Martínez et al. 2007, Walker \& Mohan 2009). While the prevalence and role in

\footnotetext{
${ }^{*}$ Corresponding author: schott@umces.edu
}

mortalities of wild fishery populations can be challenging to quantify for some pathogens (Shields et al. 2005), with others there is clear evidence of their prevalence either impacting otherwise predictable population variations (Wahle et al. 2009) or resulting in population declines (Ward \& Lafferty 2004, Hershberger et al. 2016).

In Chesapeake Bay, USA, the abundance of blue crab Callinectes sapidus can vary markedly from year to year due to fluctuations in recruitment and natural mortality (Miller et al. 2011, NOAA NMFS

(C) The authors 2018. Open Access under Creative Commons by Attribution Licence. Use, distribution and reproduction are unrestricted. Authors and original publication must be credited. 
2014, MD DNR 2017). A need has thus been identified to better understand the role of disease in this variability (CBSAC 2014). Of the viral, bacterial, fungal, protozoan and metazoan pathogens detected in blue crabs (Shields \& Overstreet 2007), at least 3 viruses can cause mortality, including a reo-like virus (RLV) also known as C. sapidus reovirus 1 (CsRV1), Chesapeake Bay virus (CBV) and bifacies virus (BFV) (Johnson 1977, 1988, Bowers et al. 2010). Although viruses have been identified to affect the ecology of many crustacean species (Butler et al. 2008, Walker \& Mohan 2009, Stentiford et al. 2012), little is known about their impact on blue crab fisheries (Johnson 1978, Shields 2003, Shields \& Overstreet 2007).

CsRV1 is the most studied virus of blue crabs (Johnson 1977, 1983) and is found throughout their North American distribution range that includes the major Chesapeake Bay and the Louisiana coast fisheries (Rogers et al. 2015, Flowers et al. 2016a). In Chesapeake Bay, CsRV1 has been detected repeatedly at $>50 \%$ prevalence (Bowers et al. 2010, Flowers et al. 2016a), and experimentally it has been demonstrated to cause disease resulting in mortality in under $2 \mathrm{wk}$ (Bowers et al. 2010).

Genome structure and sequence shows that CsRV1 is closely related to Scylla serrata reovirus (SsRV or mud crab reovirus, MCRV) (Tang et al. 2011, Flowers et al. 2016b), which has caused mass mortality of mud crabs S. serrata cultured in China (Weng et al. 2007). CsRV1 has similarly been associated with blue crab mortalities in soft-shell crab production ('shedding') systems in which wild-captured pre-molt crabs ('peelers') are held for several days until ecdysis to increase their commercial value. High CsRV1 infection loads have been found in $>50 \%$ of blue crabs that die in these systems, possibly due to multiple stressors rendering them more susceptible to disease (Ary \& Poirrier 1989). In Chesapeake Bay, shedding is often conducted in flow-through seawater systems, and dead individuals are typically discarded into adjacent waterways (Flowers et al. 2016a). As with other crustacean viruses (e.g. penaeid white spot syndrome virus; Soto \& Lotz 2001, Lightner 2005), CsRV1 is likely transmitted by scavenging, cannibalism and waterborne transmission during cohabitation (Johnson 1977, 1983).

There is a recognized potential for wild marine animal populations to be reservoirs of pathogens entering aquaculture and for aquaculture populations to amplify and disseminate pathogens to wild populations (e.g. Snow et al. 2010, Sandlund et al. 2014). Examples of the latter include sea lice Lep- eophtheirus salmonis parasitizing wild Atlantic salmon, infectious hypodermal and hematopoietic virus (IHHNV) in shrimp, and withering syndrome in abalone (Pantoja et al. 1999, Krkošek et al. 2005, Lafferty \& Ben-Horin 2013). In this context, the high prevalence and infection loads of CsRV1 in flow-through shedding systems suggest that they could provide a mechanism for amplifying and returning the virus to nearby wild populations of blue crab. To assess this, PCR was used to determine the prevalence of CsRV1 in blue crabs collected over 2 summers from locations both near to and far from flow-through soft-crab production systems. Crab sex, size and injury data were also recorded to identify host factors that might correlate with CsRV1 prevalence.

\section{MATERIALS AND METHODS}

\section{Crab sampling and environmental data}

Blue crabs were sampled from 2 locations (Deal Island and Crisfield) in the Maryland portion of Chesapeake Bay with commercial-scale flow-through shedding operations consistently in use, and from a reference location (Rhode River) near the Smithsonian Environmental Research Center with no record of shedding being undertaken. At the Crisfield and Deal Island sites, crabs were sampled at a site near to $(<200 \mathrm{~m})$ and a site far from $(>2 \mathrm{~km}$ and adjacent to undeveloped land without crab shedding operations) the shedding and shedding effluent locations (Fig. 1).

Crabs were collected at each of the 5 sites by otter trawl on 13 June and 28 August 2012 and on 21 June, 9 July, 23 July and 6 August 2013. In 2012, we collected 38 to 46 crabs at each date and site; in 2013, 12 to 28 crabs were collected at each date and site (Table 1). For each crab, sex, pre-existing injury status (based on observed regrowth or absence of an open wound for shell injuries or lost pereopods) and carapace width (measured spine-to-spine) were recorded. For crabs with $>90 \mathrm{~mm}$ carapace width tissue samples were collected by induced leg autotomy. Smaller crabs were collected whole. Crab samples were individually bagged aboard the research vessel, placed on ice for transport and stored at $-20^{\circ} \mathrm{C}$ pending RNA extraction. To confirm that CsRV1 was present in shedding facilities adjacent to the 'Near' sampling sites, CsRV1 RNA loads were quantified in dead peelers (stored at $-20^{\circ} \mathrm{C}$ ) provided by shedding operators. 


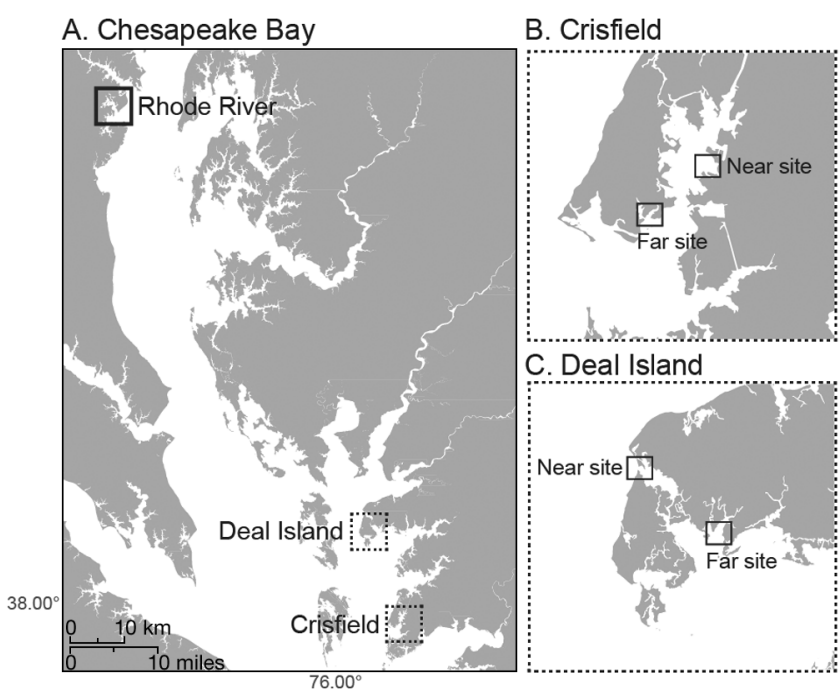

Fig. 1. Blue crab sampling locations and Near and Far sites. (A) Rhode River, Crisfield, and Deal Island in the Chesapeake Bay, and closer views of (B) Crisfield and (C) Deal Island

\section{RNA extraction and reverse transcription (RT) qPCR}

RNA extraction and RT-qPCR were conducted as described by Flowers et al. (2016a). Briefly, dissections were conducted with single-use, sterile implements and the dissection area and crab carapace were cleaned with ELIMINase ${ }^{\mathrm{TM}}$ (DeconLabs) prior to each dissection. Leg muscle ( $50 \mathrm{mg}$ ) was homogenized with glass beads in $1.0 \mathrm{ml}$ TRIzol ${ }^{\circledR}$ using a Savant FastPrep ${ }^{\mathrm{TM}}$ FP120 homogenizer, and RNA was extracted following the TRIzol protocol. To monitor for cross contamination, negative control samples (muscle from virus-free hatchery crabs) were extracted before and after sets of field samples and then subjected to RT-qPCR. RNA pellets were dissolved in $50 \mu \mathrm{l}$ nuclease-free water and stored at $-80^{\circ} \mathrm{C}$.

RT-qPCR was conducted using TaqMan ${ }^{\circledR}$ Fast Virus 1-Step Master Mix in $10 \mu \mathrm{l}$ reactions containing $0.5 \mu \mathrm{M}$ primers (RLVSet1F and RLVSet1R, Flowers et al. 2016a). Prior to thermal cycling, doublestranded RNA (dsRNA) template was denatured in the presence of primers by heating at $95^{\circ} \mathrm{C}$ for $5 \mathrm{~min}$ followed by cooling to $4{ }^{\circ} \mathrm{C}$. Standard curves were generated from PCR data generated using a 10 -fold dilution series $\left(10^{6}\right.$ to 10 CsRV1 genome copies $\left.\mu l^{-1}\right)$ of viral dsRNA purified from a CsRV1infected crab, quantified and serially diluted

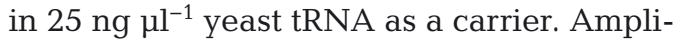
con authenticity was verified by melting point analysis. As cross-contamination of up to several hundred copies of viral RNA was occasionally detected in negative control samples, a conservative threshold for designating a crab as CsRV1positive was set at 1000 dsRNA copies per PCR reaction ( $2 \mu \mathrm{l}$ RNA) as described previously (Flowers et al. 2016a).

\section{Statistical analyses}

We aimed to determine whether CsRV1 prevalence in wild blue crabs was affected by proximity to shedding operations and whether variables such as the different times during summer, sex, injury and/or landing size were also significant predictors of infection. When sequential 2013 collections ( $2 \mathrm{wk}$ apart) at a site showed no significant difference in measured CsRV1 prevalence (tested using $\chi^{2}$ analyses), data from the 2 collection times at that site were combined. This helped group data into discrete early/late summer groupings and facilitated statistical analyses (see 'Results: Data simplification and analyses').

To determine whether CsRV1 prevalence varied significantly with crab sampling time, sex, injury and/or landing size (Table 2), binomial (infected vs. non-infected) generalized linear logistic regression models were run using an alpha of 0.05 (MASS library in R, 3.4.2; R Development Core Team 2017). The information theoretical approach was employed for model selection and assessment of model performance (Richards 2005), and initial models included all binomial parameters (Table 2). To select the model that best described CsRV1 prevalence from the set of initial models, Akaike's information criterion (AIC) was used (Burnham \& Anderson 1998). The most complex models with full interaction terms between predictor variables were run first, followed sequentially by models with all combinations of predictor variables as full and partial interactions until a simple 'main' effects model was reached. Model selections were based on the lowest AIC
Table 1. Number of blue crabs analyzed from each location and date. 'Near' and 'Far' refer to the relative distance from an aquaculture site

\begin{tabular}{|lcccccc|}
\hline Date & \multicolumn{2}{c}{$\begin{array}{c}\text { Crisfield } \\
\text { Near }\end{array}$} & $\begin{array}{c}\text { Crisfield } \\
\text { Far }\end{array}$ & $\begin{array}{c}\text { Deal Isl. Deal Isl. Rhode R. } \\
\text { Near }\end{array}$ & $\begin{array}{c}\text { Total } \\
\text { Far }\end{array}$ & Reference \\
\hline 13-Jun-12 & 46 & 38 & 38 & 40 & 42 & 204 \\
28-Aug-12 & 41 & 40 & 40 & 40 & 43 & 204 \\
21-Jun-13 & 26 & 28 & 28 & 28 & 28 & 137 \\
9-Jul-13 & 26 & 26 & 24 & 24 & 12 & 112 \\
23-Jul-13 & 22 & 23 & 25 & 25 & 16 & 111 \\
6-Aug-13 & 26 & 25 & 26 & 25 & 28 & 130 \\
\hline
\end{tabular}


Table 2. Individual Callinectes sapidus predictor variables measured in surveys

\begin{tabular}{|c|c|c|}
\hline Measurement & Description & Measure \\
\hline Infection & Infection of C. sapidus with CsRV1 & Presence vs. absence (P vs. A) \\
\hline Site & $\begin{array}{l}\text { The site at which an individual was caught based on the } \\
\text { proximity to the closest shedding facility (Crisfield vs. } \\
\text { Deal vs. Rhode also recorded) }\end{array}$ & Ordered binomial: Near vs. Far \\
\hline Month & Month in which an individual was caught & Ordered binomial: June vs. August \\
\hline Sex & Male vs. female & Binomial: male vs. female \\
\hline Injury & Wounds such as punctures and stress fractures to the cuticle & P vs. A \\
\hline Landing size & $\begin{array}{l}\text { Minimum landing size (MLS): carapace width } \\
\text { measured spine-to-spine }\end{array}$ & Ordered binomial: above vs. below MLS \\
\hline
\end{tabular}

value. Once selected, non-significant predictor variables were removed using a drop1 procedure to produce final, simpler, 'reduced models' with increased predictive power (Zuur et al. 2009).

Fitted probability plots were used to visualize the significant relationships inferred from the reduced models using carapace width as the independent variable. The probability of each of the predictor variables was calculated using the following equation:

$$
\rho=\frac{1}{1+\exp ^{-\beta x}}
$$

where $\rho$ is the probability of each response variable (measured CsRV1 prevalence) and $\beta x$ is the estimate (slope) for the predictor variable analyzed (Table 2).

\section{RESULTS}

\section{Crab metrics and variation in CsRV1 prevalence}

RNA from leg muscle tissue was amplified by RTqPCR to quantify CsRV1 dsRNA amounts in 898 wild blue crabs sampled on 6 dates from 5 sites during the summers of 2012 and 2013 (Fig. 1, Appendix Table A1). Of the crabs, $61 \%$ were males, carapace widths of all crabs ranged from 10 to $182 \mathrm{~mm}$ (mean $=80.9 \mathrm{~mm}$ ), and males were noted to be significantly larger on average compared to females sampled across both years and all sites $(t=3.62$, df $=149, \mathrm{p}<$ 0.05). Aggregate CsRV1 detection prevalence at all sites including the reference location for the 2 years was $13.5 \%$, but the prevalence was significantly higher in $2012(22 \%)$ than $2013\left(5.9 \% ; \chi^{2}=40.10, \mathrm{~N}=\right.$ $20, \mathrm{p}<0.001)$. Prevalence associations for each year were thus assessed separately (Table 3).

Discounting samples that were excluded from analysis because they may have been CsRV1-contaminated during field or laboratory manipulations (i.e.
$<1000$ dsRNA target sequences), the mean CsRV1 dsRNA loads in crabs amplified by RT-qPCR was $10^{4.7}$ dsRNA target sequences $\mathrm{mg}^{-1}$ leg muscle (range $10^{3.1}$ to $10^{9.8}$ ). Dead crabs ( $\mathrm{n}=56$ total) tested from shedding systems were CsRV1-positive on all sampling dates at prevalence levels ranging from 94 to $100 \%$. Mean CsRV1 dsRNA loads in these crabs was $10^{7.0}$ dsRNA target sequences $\mathrm{mg}^{-1}$ leg muscle (range $10^{3.3}$ to $10^{9.4}$ ). CsRV1 detection prevalence did not differ significantly in crabs with observed injury (Table 3).

\section{CsRV1 prevalence and proximity to shedding locations}

CsRV1 prevalence in crabs sampled on 13 June 2012 at both the Crisfield Near and Deal Island Near sites was significantly higher compared to the corresponding Far sites, while on 28 August 2012, only the Deal Island Near site had a CsRV1 prevalence significantly higher than the Far site (Fig. 2A). In 2013, CsRV1 prevalence at the Deal Island Near site was significantly higher than at the Far site on 6 August $\left(\chi^{2}=19.4, \mathrm{~N}=4, \mathrm{p}=0.001 ;\right.$ Fig. $\left.2 \mathrm{~B}\right)$.

Table 3. Summaries of chi-squared contingency tests and a post hoc procedure following Marascuilo \& Serlin (1988) indicating sites that had significantly different CsRV1 prevalence. C: Crisfield; D: Deal Island; R: Rhode River. Near $=1$, Far $=0$, Rhode reference $=3$. Dashes $(-)$ indicate that CsRV1 prevalence was too low to make meaningful comparisons. NS: not significant

\begin{tabular}{|ccccc|}
\hline Year & Month & $\begin{array}{c}\text { Near vs. } \\
\text { Near }\end{array}$ & $\begin{array}{c}\text { Far vs. } \\
\text { Far }\end{array}$ & $\begin{array}{c}\text { Far vs. } \\
\text { Control }\end{array}$ \\
\hline 2012 & Jun & NS & NS & D0 vs. R3 \\
& Aug & C1 vs. D1 & NS & D0 vs. R3 \\
2013 & Jun & NS & NS & NS \\
& Aug & - & - & - \\
\hline
\end{tabular}



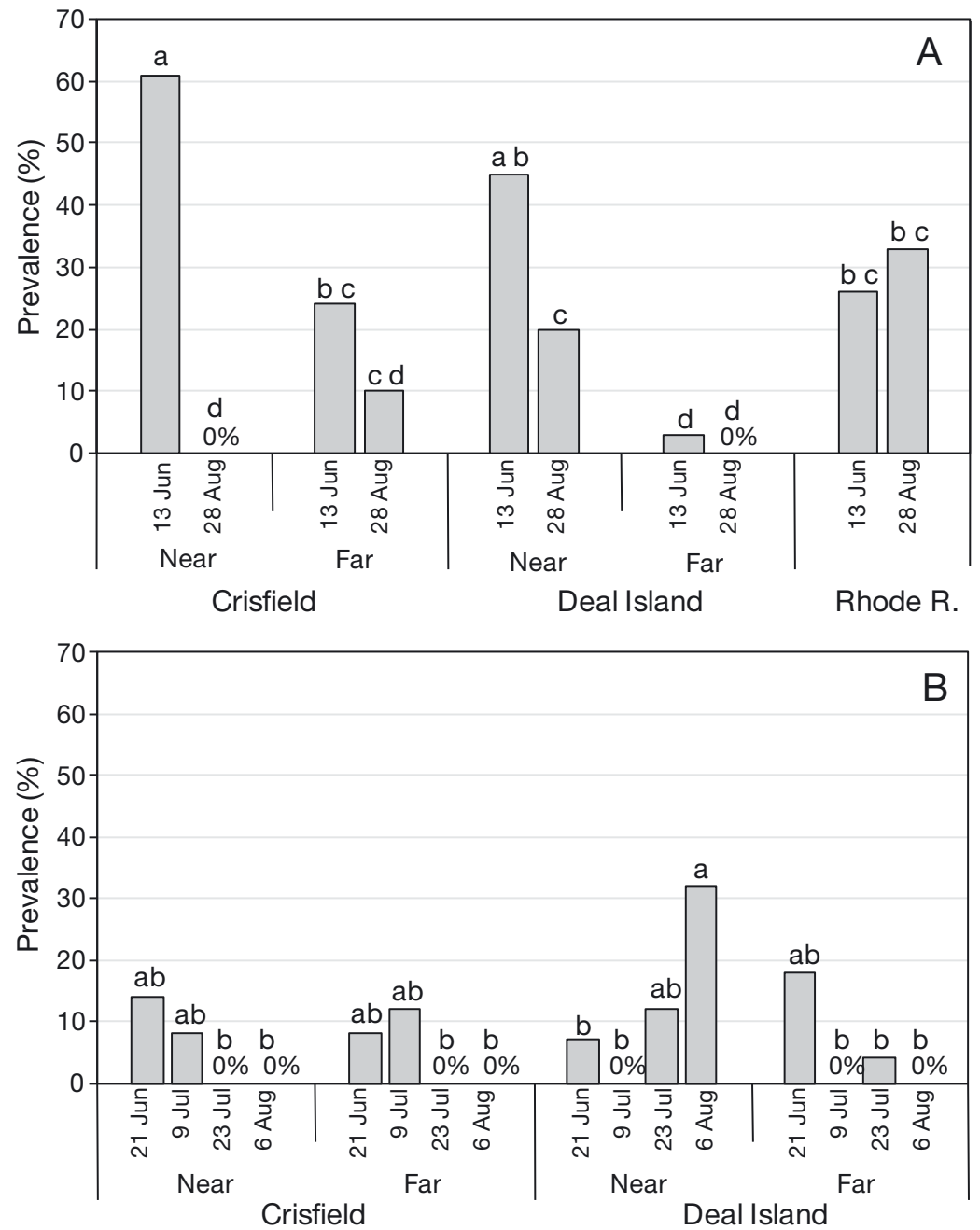

Fig. 2. CsRV1 prevalence in blue crabs determined using RT-qPCR. (A) Crabs sampled in 2012 on 13 June and 28 August from Rhode River, Crisfield and Deal Island, MD. Crisfield and Deal Island locations each have Near and Far sampling sites. Letters a-d refer to CsRV1 prevalence not differing significantly by Fisher's exact test ( $p>0.05)$. (B) Crabs sampled in 2013 from the same locations and sites as in A. Letters a and b refer to CsRV1 prevalence not differing significantly by Fisher's exact test $(p>0.05)$. Because CsRV1 was not detected in any Rhode River crabs $(\mathrm{N}=84)$ in 2013 , those data are not displayed

\section{Within-site CsRV1 prevalence between sampling times}

At sites both near to and far from shedding systems in Crisfield and Deal Island in 2012, CsRV1 prevalence declined in the $10 \mathrm{wk}$ between 13 June and 28 August ( $\mathrm{p}<0.05 ; 61$ to $0 \%$ at Crisfield, 45 to $20 \%$ at Deal Island). The Rhode River Control location displayed no significant change in prevalence between the June (26\%) and August (33\%) sampling times.

In 2013, CsRV1 prevalence at the Deal Island Near site increased significantly between 21 June and 6
August when it was $32 \%$, the highest prevalence measured for 2013. There were no other significant differences between sites during 2013 (Fig. 2B). Because none of the crabs sampled from the Rhode River site in 2013 ( $N=84$ ) were CsRV1-positive, these data are excluded from Fig. 2B.

\section{Modelling predictors of CsRV1 detection}

\section{Data simplification and analyses}

To generate and interpret the generalized linear models (GLMs), a number of date-site measurements were combined as justified by $\chi^{2}$ analyses. To compare between summers using early and late summer sampling dates, 2013 data from crabs sampled on 21 June and 9 July (referred to as June data) and on 23 July and 6 August (referred to as August data) were combined. This was justified statistically, as the percentage of CsRV1-positive individuals did not differ significantly between 23 July and 6 August for any of the sites in $2013\left(\chi^{2}=2.31, N=5, p=0.316\right)$.

Of the 10 possible within-site June vs. August comparisons, only a single site differed significantly in either 2012 or 2013. These were the 2012 Crisfield Near site (C1), at which $61 \%$ crabs sampled on 13 June were CsRV1-positive compared to $0 \%$ sampled on 28 August $\left(\chi^{2}=33.59, \mathrm{~N}=1, \mathrm{p}<\right.$ 0.001), and 2013 Deal Far site (D0), where $10 \%$ of crabs sampled in June were CsRV1positive compared to $1.4 \%$ of crabs sampled in August ( $\left.\chi^{2}=10.28, \mathrm{~N}=1, \mathrm{p}<0.001\right)$.

Comparing sites hypothesized to be similar in CsRV1 prevalence (Table 3, Near vs. Near, Far vs. Far, Control vs. Far), in 2012 this differed significantly among crabs sampled from the Rhode River Control (R3) and Deal Far sites (D0) on 13 June $\left(\chi^{2}=36.58, \mathrm{~N}=4, \mathrm{p}<0.001\right)$ and 28 August $\left(\chi^{2}=27.74, \mathrm{~N}=4, \mathrm{p}<0.001\right)$. A significant difference was also identified among crabs sampled from the Crisfield Near site (C1) and Deal Near site (D1) on 28 August $2012\left(\chi^{2}=24.2, \mathrm{~N}=4, \mathrm{p}<0.001\right)$. In 2013, none of the hypothetically similar sites showed significant differences in post hoc tests (Table 3).

Considering that only 1 Near vs. Near or Far vs. Far site comparison (C1 vs. D1, 28 August 2012) showed a difference in CsRV1 prevalence, data on crabs from Crisfield and Deal were combined to create a single 
Table 4. Final full 2012 and 2013 models used to predict response variables of infection before model reduction. The final full model has the lowest Akaike's information criterion (AIC) of all combinations of predictor variables (see Table 2) as full and partial interactions. ${ }^{*}$ denotes significance $\left({ }^{*} \mathrm{p}<0.05,{ }^{* *} \mathrm{p}<0.001,{ }^{* * *} \mathrm{p}<0.001\right)$

\begin{tabular}{|c|c|c|c|}
\hline Final full model & Predictor variable & Estimate (slope) & $\mathrm{p}$ \\
\hline \multicolumn{4}{|l|}{2012} \\
\hline Infected $\sim$ Site + Month $+($ Sex $\times$ Injury $)+$ Landing size & Site & -1.30 & $0.001^{* *}$ \\
\hline AIC: 198.77 & Month & $-1.5 \times 10^{-4}$ & $<0.001^{* * *}$ \\
\hline \multirow[t]{4}{*}{$\mathrm{df}=231$} & Sex & 0.66 & 0.150 \\
\hline & Injury & 0.86 & 0.214 \\
\hline & Landing size & -0.49 & 0.307 \\
\hline & Sex $\times$ Injury & -1.50 & 0.101 \\
\hline \multicolumn{4}{|l|}{2013} \\
\hline Infected $\sim($ Site $\times$ Month $)+$ Sex + Injury + Landing size & Site & 5.20 & 0.094 \\
\hline AIC: 211.01 & Month & $-4.80 \times 10^{-7}$ & 0.986 \\
\hline \multirow[t]{4}{*}{$\mathrm{df}=385$} & Sex & 0.91 & $0.043^{*}$ \\
\hline & Injury & 0.20 & 0.685 \\
\hline & Landing size & -1.14 & $0.015^{*}$ \\
\hline & Site $\times$ Month & $-7.9 \times 10^{-5}$ & 0.062 \\
\hline
\end{tabular}

binomial measure ('Site') of proximity to shedding facilities (Near vs. Far). The CsRV1 prevalence at Near and Far sites in 2012 showed similar patterns (high on 13 June, lower on 28 August). Site data (e.g. $\mathrm{C} 1+\mathrm{D} 1=$ Near, $\mathrm{C} 0+\mathrm{D} 0=$ Far) were combined to determine and interpret GLMs.

\section{GLM analyses}

The regression models giving the smallest magnitude AIC values of the predictor variable combinations were those with only 1 interaction term. For the 2012 data, AIC values were best between crab sex and pre-existing injury and for the 2013 data, between sampling site and sampling month (June or August samplings; Tables 4 \& 5). Both 'final full' models differed significantly from null models $(\mathrm{p}<$ 0.001). The final full GLM selected for 2012 showed that sampling time (13 June vs. 28 August) influenced CsRV1 prevalence most significantly followed by sampling site (Near vs. Far). Following model reduction using the drop1 procedure, overall, in 2012, crabs sampled on 28 August had up to $41 \%$ higher probability of being CsRV1-positive than those sampled on 13 June and up to a $78 \%$ higher probability of being CsRV1-positive if samples were from sites near rather than far from shedding facilities (Fig. 3). In 2013, CsRV1 prevalence was influenced most significantly by crab landing size (above vs. below minimum landing size of $127 \mathrm{~mm}$ ) and sex. CsRV1 prevalence was 61 to $72 \%$ more probable in males and $21 \%$ more likely in crabs over the minimum landing size (Fig. 4).

\section{DISCUSSION}

GLMs of CsRV1 prevalence in blue crabs sampled from 5 different sites at 3 locations in Chesapeake Bay over the summers of 2012 and 2013 showed that it was associated significantly with site within location and sampling month in 2012, and with crab sex and size in 2013. Overall, CsRV1 prevalence was significantly lower in 2013 than in 2012. The underlying data used in GLM analyses revealed within-year prevalence to vary substantially depending on sampling date and/or location.

Table 5. Final reduced 2012 and 2013 models used to predict response variables of infection before model reduction. The final reduced model is derived by sequential drop1 of non-significant predictor variables (see Table 2) from each final full model. ${ }^{*}$ denotes significance $\left({ }^{*} \mathrm{p}<0.05,{ }^{* *} \mathrm{p}<\right.$ $\left.0.001,{ }^{* * *} \mathrm{p}<0.001\right) ;$ AIC: Akaike's information criterion

\begin{tabular}{|lccr|}
\hline Final reduced model & Predictor variable & Estimate (slope) & $\mathrm{p}$ \\
\hline $\mathbf{2 0 1 2}$ & & & \\
Infected $\sim$ Site + Month & Site (Far) & -1.2 & $0.0017^{* *}$ \\
AIC: 195.17 & Month (Aug) & $-1.1 \times 10^{-4}$ & $<0.001^{* * *}$ \\
df $=235$ & & \\
$\mathbf{2 0 1 3}$ & & & $0.049^{*}$ \\
Infected $\sim$ Sex + Landing size & Sex (male) & 0.875 & \\
AIC: 211.35 & & & \\
df $=389$ & & & \\
\hline
\end{tabular}



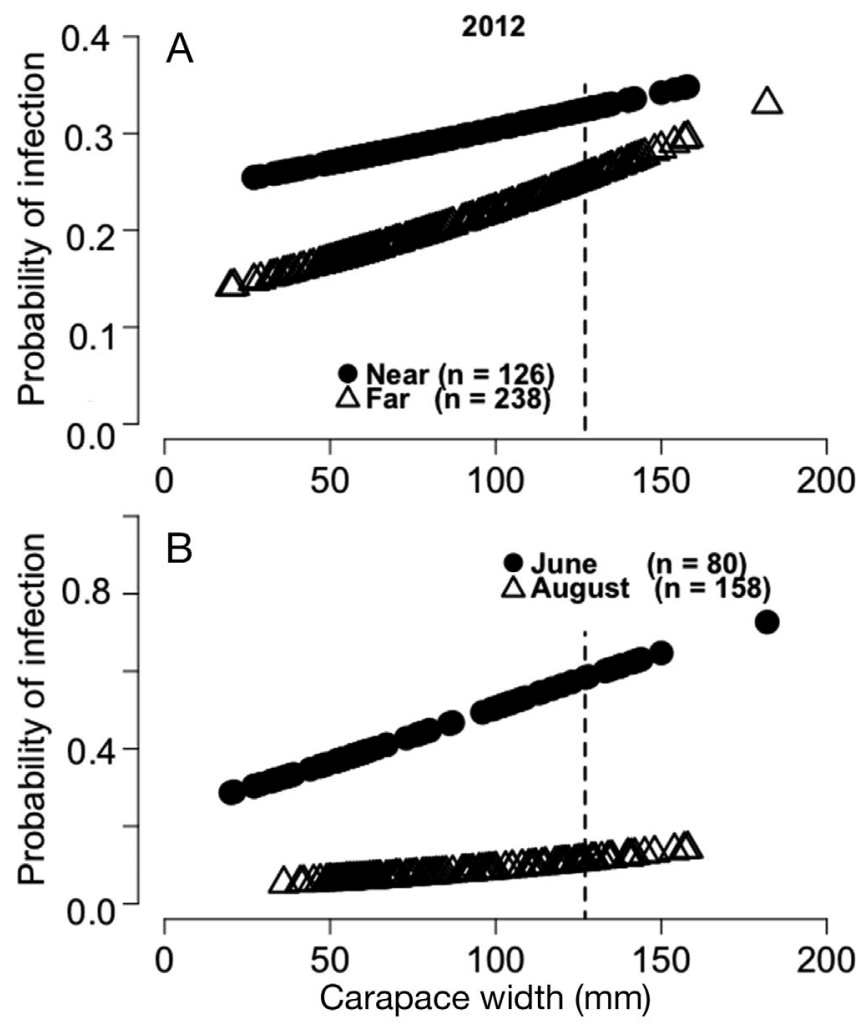

Fig. 3. Fitted probability plots of CsRV1 infection against carapace width of crabs sampled in 2012, separated by significant predictor variables from the final reduced model: (A) proximity to shedding facility and (B) month. The broken line represents the minimum landing size. Note that the $y$ axis scales differ between the 2 plots

\section{CsRV1 prevalence and proximity to flow-through aquaculture}

CsRV1 prevalence in wild blue crabs relative to their size and sex, proximity to shedding operations and time of sampling was evaluated in the context of principles theorized to operate in marine infection systems as reviewed by Grant \& Jones (2010). Prevalence was higher by statistically significant amounts $(p>0.05)$ at Near sites in 3 of the 4 Near-Far site comparisons in 2012 (13 June at both Deal Island and Crisfield) and in 1 of the 5 comparisons in 2013 (6 August at Deal Island) in which CsRV1 was detected. As prevalence levels varied insignificantly either way in the other 5 comparisons, the findings were consistent with other crustacean species in which pathogens or parasites amplified in aquaculture systems have been found to impact local wild populations (Krkošek et al. 2011, Lafferty \& Ben-Horin 2013). CsRV1 was detected at high levels by PCR in the majority of the dead crabs sampled from flow-through shed-

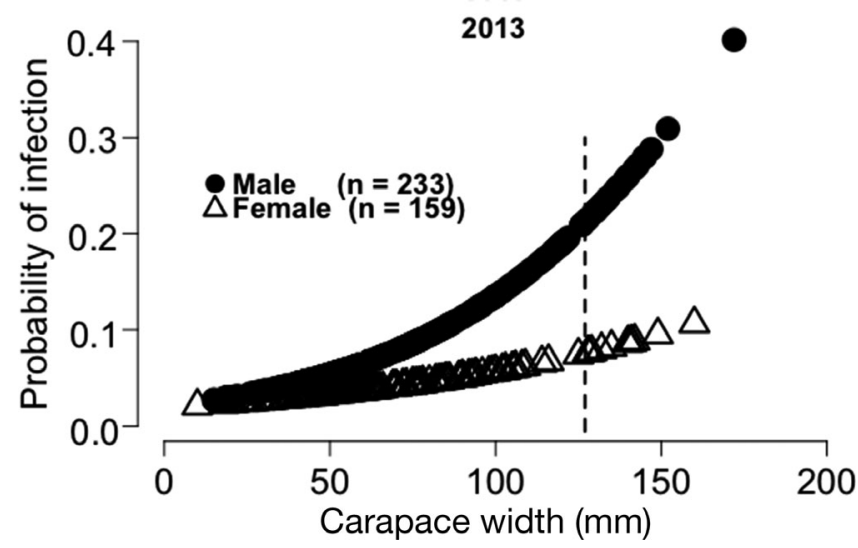

Fig. 4. Fitted probability plots of CsRV1 infection against carapace width of crabs sampled in 2013, separated by the significant sex predictor variable from the final reduced model. The broken line represents the minimum landing size

ding systems, as found previously (Bowers et al. 2010), suggesting that CsRV1 might be discharged in effluents. Field observations and conversations with fishers (E. M. Flowers unpubl.) revealed that dead peelers are often returned to the waters from which they were fished, many kilometers from the shedding facilities. Further studies are thus warranted to determine to what extent effluents might represent a biosecurity risk and shedding system workers understand the biosecurity risk of discarding dead peelers back into environments from which they were captured.

\section{Spatial variation in CsRV1 prevalence}

CsRV1 prevalence varied markedly (up to $42 \%$ ) among blue crabs sampled at sites as little as $\sim 2 \mathrm{~km}$ apart, as observed previously among crabs sampled from either different US states (78\% variation) along the Atlantic coast or locations $50-100 \mathrm{~km}$ apart within Chesapeake Bay (40\% variation, Flowers et al. 2016a). This finding that factors influencing CsRV1 prevalence can differ over relatively short distances are reminiscent of Panulirus argus virus 1 (PaV1) prevalence varying by $68 \%$ among spiny lobsters sampled from locations $<30 \mathrm{~km}$ apart (Moss et al. 2012).

\section{Temporal variation and trends in CsRV1 prevalence}

CsRV1 prevalence at specific sites varied significantly among crabs sampled 4 to 9 wk apart, such as 
the Crisfield and Deal Island Near sites where it declined between 13 June and 28 August 2012. As crabs migrate in and out of Chesapeake Bay throughout the summer (Hines 2007), this decline might have been due to some infected crabs either leaving or dying or a combination of both. In 2013, CsRV1 prevalence increased by $32 \%$ at the Deal Island Near site between 9 July and 6 August and varied over time at lower Chesapeake Bay sites. However, it remained relatively stable at reference Rhode River sites sampled at different times in 2012 and 2013. The reasons for these locational differences are not known and highlight the need for more sophisticated approaches to tracking movements and mortality rates of CsRV1-infected crabs over spring through to autumn.

Overall CsRV1 prevalence in the blue crabs examined was $22 \%$ in 2012 and $6 \%$ in 2013 compared to $21 \%$ in 2010 (Flowers et al. 2016a). Interestingly, the estimated size of the blue crab population in Chesapeake Bay in 2012 (720 million) was similar to that in 2010 (670 million) but almost double the long-term average (380 million) and over double that estimated in 2013 (290 million) (CBSAC 2014, MD DNR 2017). These data suggest that increased crab population density might lead to increased CsRV1 prevalence, as has been reported in other marine pathogen-host systems (Lafferty 2004). However, this correlation needs to be confirmed in multi-year studies of CsRV1 prevalence as well as the natural routes by which wild crabs acquire these infections.

\section{Crab metrics and CsRV1 prevalence}

The prevalence of CsRV1 was higher in larger and/or male crabs, as captured males were generally larger than females. Of the crabs sampled in 2013, CsRV1 prevalence was >3-fold higher in males than in females. Further studies are needed to determine the reason for these differences. However, it is reasonable to expect that larger crabs will have had greater opportunities to be exposed to CsRV1 in water and through aggressive interactions with other crabs and conspecific predation (Moksnes et al. 1997, Ryer et al. 1997). Fishery interactions could also influence prevalence. For example, in years when crab numbers are low, a greater proportion of larger landing size crabs more likely to be infected with CsRV1 might be trapped, thus depleting the proportion of such crabs remaining in the wild population. There are over 500000 crab traps in the Maryland portion of
Chesapeake Bay alone (MD DNR 2012), and we speculate that the majority of blue crabs in the Bay encounter at least 1 trap by the time they mature. A study of PaV1 transmission among spiny lobsters cohabitating traps identified transmission to increase with prolonged residence in a trap (Behringer et al. 2012).

The finding of a higher CsRV1 infection probability in males has not been reported in previous studies (Bowers et al. 2010, Flowers et al. 2016a). However, these involved opportunistic specimen collections from crabbers that comprised fewer small crabs as the standardized trawl method used here. While the reasons for the increased CsRV1 prevalence in males is not clear, male-female behavioral differences cannot be discounted. For example, as females must return to the mouth of the Chesapeake Bay to release larvae, their migration patterns differ from those of males (Aguilar et al. 2005). The mating process might also be involved, as pre-pubertal females are 'cradled' by male crabs for 2 or $3 \mathrm{~d}$ during the time the females molt. Moreover, while females mate once, males may mate with multiple females, thus increasing their opportunities to come into contact with CsRV1.

In summary, the data reported here identified evidence for the prevalence of CsRV1 being higher in wild blue crabs captured close to flow-through shedding facilities compared to more distant locations. However, prevalence at some locations varied between 2012 and 2013, and CsRV1 was also detected more frequently in males and larger females. More sophisticated longitudinal multi-location studies of larger crab numbers will be needed to identify reasons for much of the data obtained. As CsRV1 is consistently pathogenic to captive blue crabs (Bowers et al. 2010, unpublished data), how it impacts wild crabs also still needs to be determined, perhaps through simple but extensive tag-testrecapture studies.

Acknowledgements. E.J.S. and E.M.F. received major funding from MD Sea Grant (NA10OAR4170072), and additional funding from NOAA S-K (NA15NMF4270296). E.M.F. was supported in part by Trish and Mike Davis. A.F.J. was supported by NSF grant DEB-1632648 (2016). We thank Brianne Walsh of the University of Maryland Center for Environmental Science for assistance with figures. We are very grateful for the indispensable cooperation of fishermen and soft crab producers in Deal Island and Crisfield, especially Linda Labo, Sam Insley, Hilda Marshall, and Dan Webster. We thank Mike Goodison, Paige Roberts, and Kim Richie at the Smithsonian Environmental Research Center for field work and help with data collection. 


\section{LITERATURE CITED}

Aguilar R, Hines AH, Wolcott TG, Wolcott DL, Kramer MA, Lipcius RN (2005) The timing and route of movement and migration of post-copulatory female blue crabs, Callinectes sapidus Rathbun, from the upper Chesapeake Bay. J Exp Mar Biol Ecol 319:117-128

Ary RD Jr, Poirrier MA (1989) Acute toxicity of nitrite to the blue crab (Callinectes sapidus). Prog Fish-Cult 51: 69-72

Behringer DC, Butler MJI, Moss J, Shields JD (2012) PaV1 Infection in the Florida spiny lobster (Panulirus argus) fishery and its effects on trap function and disease transmission. Can J Fish Aquat Sci 69:136-144

Bowers HA, Messick GA, Hanif A, Jagus R, Carrion L, Zmora O, Schott EJ (2010) Physicochemical properties of double-stranded RNA used to discover a reo-like virus from blue crab Callinectes sapidus. Dis Aquat Org 93: 17-29

Burnham KP, Anderson DR (1998) Model selection and multimodel inference. Springer, Berlin

Butler MJ, Behringer DC, Shields JD (2008) Transmission of Panulirus argus virus 1 (PaV1) and its effect on the survival of juvenile Caribbean spiny lobster. Dis Aquat Org 79:173-182

Canadian Science Advisory Secretariat (2010) Pathways of effects for finfish and shellfish aquaculture. Science Advisory Report 2009/071. Fisheries and Oceans Canada. www.dfo-mpo.gc.ca/csas/csas/Publications/SAR-AS/ 2009/2009_071_E.pdf

CBSAC (Chesapeake Bay Stock Assessment Committee) (2014) 2014 Chesapeake Bay blue crab advisory report. NOAA Chesapeake Bay Office, Annapolis, MD. www.chesapeakebay.net/what/publications

Field RH, Chapman CJ, Taylor AC, Neil DM, Vickerman K (1992) Infection of the Norway lobster Nephrops norvegicus by a Hematodinium-like species of dinoflagellate on the west coast of Scotland. Dis Aquat Org 13:1-15

Flowers EM, Simmonds K, Messick GA, Sullivan L, Schott EJ (2016a) PCR-based prevalence of a fatal reovirus of the blue crab, Callinectes sapidus (Rathbun), along the northern Atlantic coast of the USA. J Fish Dis 39:705-714

Flowers EM, Bachvaroff TR, Warg JV, Neill JD and others (2016b) Genome sequence analysis of CsRV1, a pathogenic reovirus that infects the blue crab Callinectes sapidus across its trans-hemispheric range. Front Microbiol 7:126

Hershberger PK, Garver KA, Winton JR (2016) Principles underlying the epizootiology of viral hemorrhagic septicemia in Pacific herring and other fishes throughout the North Pacific Ocean. Can J Fish Aquat Sci 73:853-859

Hines AH (2007) Ecology of juvenile and adult blue crabs. In: Kennedy VS, Cronin LE (eds) The blue crab: Callinectes sapidus. Publication UM-SG-TS-2007-1. Maryland Sea Grant College, College Park, MD, p 223-339

Johnson PT (1977) A viral disease of the blue crab, Callinectes sapidus: histopathology and differential diagnosis. J Invertebr Pathol 29:201-209

Johnson PT (1978) Viral diseases of the blue crab, Callinectes sapidus. Mar Fish Rev 40:13-15

Johnson PT (1983) Diseases caused by viruses, rickettsiae, bacteria, and fungi. In: Provenzano AJ Jr (ed) The biology of the Crustacea, Vol 6. Pathobiology. Academic Press, New York, NY, p 1-78

Johnson PT (1988) Development and morphology of an unusual nuclear virus of the blue crab Callinectes sapidus. Dis Aquat Org 4:67-75

Krkošek M, Lewis MA, Volpe JP (2005) Transmission dynamics of parasitic sea lice from farm to wild salmon. Proc R Soc B 272:689-696

Krkošek M, Connors BM, Morton A, Lewis MA, Dill LM, Hilborn R (2011) Effects of parasites from salmon farms on productivity of wild salmon. Proc Natl Acad Sci USA 108:14700-14704

* Lafferty KD (2004) Fishing for lobsters indirectly increases epidemics in sea urchins. Ecol Appl 14:1566-1573

* Lafferty KD, Ben-Horin T (2013) Abalone farm discharges the withering syndrome pathogen into the wild. Front Microbiol 4:373

* Lightner DV (2005) Biosecurity in shrimp farming: pathogen exclusion through use of SPF stock and routine surveillance. J World Aquacult Soc 36:229-248

Marascuilo LA, Serlin RC (1988) Statistical methods for the social and behavioral sciences. W. H. Freeman, New York, NY

MD DNR (Maryland Department of Natural Resources) (2012) Commercial fishing licenses \& fees. http://dnr. maryland.gov/fisheries/pages/commercial-license.aspx

MD DNR (2017) Blue crab winter dredge survey. http://dnr. maryland.gov/fisheries/Pages/blue-crab/dredge.aspx

* Meyers TR, Koeneman TM, Botelho C, Short S (1987) Bitter crab disease: a fatal dinoflagellate infection and marketing problem for Alaskan Tanner crabs Chionoecetes bairdi. Dis Aquat Org 3:195-216

Miller TJ, Wilberg MJ, Colton AR, Davis GR and others (2011) Stock assessment of the blue crab in Chesapeake Bay. UMCES Tech Ser No. TS-614-11. University of Maryland Center for Environmental Science Chesapeake Biological Laboratory, Solomons, MD

*Moksnes PO, Lipcius RN, Pihl L, van Montfrans J (1997) Cannibal-prey dynamics in young juveniles and postlarvae of the blue crab. J Exp Mar Biol Ecol 215:157-187

*Moss J, Butler MJ IV, Behringer DC, Shields JD (2012) Genetic diversity of the Caribbean spiny lobster virus, Panulirus argus virus 1 (PaV1), and the discovery of PaV1 in lobster postlarvae. Aquat Biol 14:223-232

NOAA NMFS (2014) Commercial fisheries statistics. https://www.st.nmfs.noaa.gov/st1/commercial/landings/ annual_landings.html

*Pantoja CR, Lightner DV, Holtschmit HK (1999) Prevalence and geographic distribution of IHHN parvovirus in wild penaeid shrimp (Crustacea: Decapoda) from the Gulf of California, Mexico. J Aquat Anim Health 11:23-34

R Development Core Team (2017) R: a language and environment for statistical computing. R Foundation for Statistical Computing, Vienna

Richards SA (2005) Testing ecological theory using the information-theoretic approach: examples and cautionary results. Ecology 86:2805-2814

* Rogers HA, Taylor SS, Hawke JP, Schott EJ, Anderson Lively JA (2015) Disease, parasite, and commensal prevalences for blue crab Callinectes sapidus at shedding facilities in Louisiana, USA. Dis Aquat Org 112: $207-217$

* Ryer CH, van Montfrans J, Moody KE (1997) Cannibalism, refugia and the molting blue crab. Mar Ecol Prog Ser 147:77-85

Sánchez-Martínez JG, Aguirre-Guzmán G, Mejía-Ruíz H (2007) White spot syndrome virus in cultured shrimp: a review. Aquacult Res 38:1339-1354 
Sandlund N, Gjerset B, Bergh Ø, Modahl I, Olesen NJ, Johansen R (2014) Screening for viral hemorrhagic septicemia virus in marine fish along the Norwegian coastal line. PLOS ONE 9:e108529

Shields JD (2003) Research priorities for diseases of the blue crab Callinectes sapidus. Bull Mar Sci 72:505-517

Shields JD, Overstreet RM (2007) Diseases, parasites, and other symbionts. In: Kennedy VS, Cronin LE (eds) The blue crab: Callinectes sapidus. Publication UM-SG-TS2007-1. Maryland Sea Grant College, College Park, MD, p 223-339

Shields JD, Taylor DM, Sutton SG, O'Keefe PG, Ings DW, Pardy AL (2005) Epidemiology of bitter crab disease (Hematodinium sp.) in snow crabs Chionoecetes opilio from Newfoundland, Canada. Dis Aquat Org 64:253-264

Snow M, Black J, Matejusova I, McIntosh R, Baretto E, Wallace IS, Bruno DW (2010) Detection of salmonid alphavirus RNA in wild marine fish: implications for the origins of salmon pancreas disease in aquaculture. Dis Aquat Org 91:177-188

Soto MA, Lotz JM (2001) Epidemiological parameters of white spot syndrome virus infections in Litopenaeus vannamei and L. setiferus. J Invertebr Pathol 78:9-15

Stentiford GD, Neil DM, Peeler EJ, Shields JD and others
(2012) Disease will limit future food supply from the global crustacean fishery and aquaculture sectors. J Invertebr Pathol 110:141-157

Tang KF, Messick GA, Pantoja CR, Redman RM, Lightner DV (2011) Histopathological characterization and in situ detection of Callinectes sapidus reovirus. J Invertebr Pathol 108:226-228

*Wahle RA, Gibson M, Fogarty M (2009) Distinguishing disease impacts from larval supply effects in a lobster fishery collapse. Mar Ecol Prog Ser 376:185-192

Walker PJ, Mohan CV (2009) Viral disease emergence in shrimp aquaculture: origins, impacts and the effectiveness of health management strategies. Rev Aquacult 1: $125-154$

*Ward JR, Lafferty KD (2004) The elusive baseline of marine disease: Are diseases in ocean ecosystems increasing? PLOS Biol 2:e120

*Weng SP, Guo ZX, Sun JJ, Chan SM, He JG (2007) A reovirus disease in cultured mud crab, Scylla serrata, in southern China. J Fish Dis 30:133-139

Zuur AF, Ieno EN, Walker NJ, Saveliev AA, Smith GM (2009) Mixed effects models and extensions in ecology with R. Springer Science and Business Media, New York, NY

\section{Appendix.}

Table A1. Summary of crab metrics. There was no significant difference in CsRV1 prevalence between crab sex, molt stage and injury categories. Because of data recording gaps, the totals for sex and molt stage do not match the total number of crabs (898) in the study. Molt stage was not recorded for all crabs

\begin{tabular}{|lccc|}
\hline Category & Number & \% total & \% CsRV1+ \\
\hline Sex & & & \\
Male & 544 & 60.9 & 14.7 \\
Female & 350 & 39.1 & 11.7 \\
Molt stage & & & \\
Intermolt & 184 & 20.6 & 7.6 \\
Premolt & 388 & 43.4 & 9.3 \\
Postmolt & 102 & 11.4 & 4.9 \\
Not categorized & 221 & 24.7 & 29.9 \\
Injury status & & & \\
Uninjured & 734 & 81.7 & 13.1 \\
Prior injury & 164 & 18.3 & 15.2 \\
\hline
\end{tabular}

Editorial responsibility: Jeff Cowley, St. Lucia, Queensland, Australia
Submitted: August 4, 2017; Accepted: April 4, 2018

Proofs received from author(s): June 15, 2018 